\title{
Correction to: French adaptation of the Five-Factor Borderline Inventory-Short Form
}

\author{
Julian A. Nasello ${ }^{1,2}$ (D) Adélaïde Blavier ${ }^{2}$ (D) - Jean-Marc Triffaux ${ }^{1,3}$ (D) \\ (C) Springer Science+Business Media, LLC, part of Springer Nature 2021
}

Correction: Current Psychology (2021). https://doi.org/10.1007/s12144-021-01878-2

The original version of this article unfortunately contained a mistake. Tables 1 and 2 should be inverted. Table 1 is a descriptive statistics table, and Table 2 is a correlation table. The original article has been corrected.

Publisher's Note Springer Nature remains neutral with regard to jurisdictional claims in published maps and institutional affiliations.

The online version of the original article can be found at https://doi.org/ 10.1007/s12144-021-01878-2

Julian A. Nasello

julian.nasello@gmail.com

1 Psychosomatic Medicine and Group Psychotherapy, Psychiatric Day Hospital « La Clé », Boulevard de la Constitution 153,

4020 Liège, Belgium

2 Department of Clinical Psychology, University of Liège, Liège, Belgium

3 Department of Psychiatry, Medicine, University of Liège, CHU of Liège, Liège, Belgium 